\title{
Front Matter: Volume 6659
}

, "Front Matter: Volume 6659," Proc. SPIE 6659, Organic-based Chemical and Biological Sensors, 665901 (24 September 2007); doi: 10.1117/12.774026

SPIE Event: Photonic Devices + Applications, 2007, San Diego, California, United SPIE. States 


\section{PROCEEDINGS OF SPIE}

\section{Organic-based Chemical \\ and Biological Sensors}

Ruth Shinar

George G. Malliaras

Editors

28 August 2007

San Diego, California, USA

Volume 6659 
The papers included in this volume were part of the technical conference cited on the cover and title page. Papers were selected and subject to review by the editors and conference program committee. Some conference presentations may not be available for publication. The papers published in these proceedings reflect the work and thoughts of the authors and are published herein as submitted. The publisher is not responsible for the validity of the information or for any outcomes resulting from reliance thereon.

Please use the following format to cite material from this book:

Author(s), "Title of Paper," in Organic-based Chemical and Biological Sensors, edited by Ruth Shinar, George G. Malliaras, Proceedings of SPIE Vol. 6659 (SPIE, Bellingham, WA, 2007) Article CID Number.

ISSN 0277-786X

ISBN 9780819468079

Published by

SPIE

P.O. Box 10, Bellingham, Washington 98227-0010 USA

Telephone +1 3606763290 (Pacific Time) · Fax +1 3606471445

SPIE.org

Copyright (C 2007, Society of Photo-Optical Instrumentation Engineers

Copying of material in this book for internal or personal use, or for the internal or personal use of specific clients, beyond the fair use provisions granted by the U.S. Copyright Law is authorized by SPIE subject to payment of copying fees. The Transactional Reporting Service base fee for this volume is $\$ 18.00$ per article (or portion thereof), which should be paid directly to the Copyright Clearance Center (CCC), 222 Rosewood Drive, Danvers, MA 01923. Payment may also be made electronically through CCC Online at copyright.com. Other copying for republication, resale, advertising or promotion, or any form of systematic or multiple reproduction of any material in this book is prohibited except with permission in writing from the publisher. The CCC fee code is $0277-786 \mathrm{X} / 07 / \$ 18.00$.

Printed in the United States of America.

Publication of record for individual papers is online in the SPIE Digital Library.

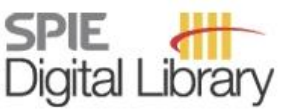

SPIEDigitallibrary.org

Paper Numbering: Proceedings of SPIE follow an e-First publication model, with papers published first online and then in print and on CD-ROM. Papers are published as they are submitted and meet publication criteria. A unique, consistent, permanent citation identifier (CID) number is assigned to each article at the time of the first publication. Utilization of CIDs allows articles to be fully citable as soon they are published online, and connects the same identifier to all online, print, and electronic versions of the publication. SPIE uses a six-digit CID article numbering system in which:

- The first four digits correspond to the SPIE volume number.

- The last two digits indicate publication order within the volume using a Base 36 numbering system employing both numerals and letters. These two-number sets start with 00, 01, 02, 03, 04, 05, $06,07,08,09,0 A, 0 B \ldots 0 Z$, followed by $10-12,20-2 Z$, etc.

The CID number appears on each page of the manuscript. The complete citation is used on the first page, and an abbreviated version on subsequent pages. Numbers in the index correspond to the last two digits of the six-digit CID number. 


\section{Contents}

$\checkmark \quad$ Conference Committee

\section{SESSION 1 ORGANIC-BASED SENSING APPLICATIONS I}

665904 Organic field effect based sensors for body parameters monitoring (Invited Paper) [6659-03]

A. Bonfiglio, I. Manunza, Univ. of Cagliari (Italy) and INFM-CNR (Italy); A. Caboni, W. Cambarau, M. Barbaro, Univ. of Cagliari (Italy)

665905 Highly fluorescent bipyridazines for acid detector [6659-04]

J. Do, Y. Kim, J. Yoo, E. Kim, Yonsei Univ. (South Korea); A.-J. Attias, Univ. Pierre et Marie Curie (France)

\section{SESSION 2 ORGANIC-BASED SENSING APPLICATIONS II}

665906 Recent developments in OLED-based chemical and biological sensors (Invited Paper) [6659-05]

J. Shinar, Z. Zhou, Y. Cai, R. Shinar, lowa State Univ. (USA)

665907 OLED-based sensor array for simultaneous monitoring of multiple analytes [6659-06]

Y. Cai, R. Shinar, Z. Zhou, J. Shinar, lowa State Univ. (USA)

665908 Polymer-based micro-array sensors [6659-07]

R. B. A. Sharpe, P. A. Rensing, G. T. van Heck, B. A. M. Allard, M. M. Koetse,

N. N. M. M. Meulendijks, P. G. M. Kruijt, M. W. W. J. Tijdink, R. M. de Zwart, S. J. J. F. van Veen,

H. F. M. Schoo, TNO (Netherlands)

665909 Organic semiconductor lasers as integrated light sources for optical sensor systems [6659-08]

M. Punke, T. Woggon, M. Stroisch, B. Ebenhoch, U. Geyer, C. Karnutsch, M. Gerken, U. Lemmer, Univ. Karlsruhe (Germany); M. Bruendel, Forschungszentrum Karlsruhe GmbH

(Germany); J. Wang, T. Weimann, Physikalisch-Technische Bundesanstalt (Germany)

\section{SESSION 3 ORGANIC-BASED SENSING APPLICATIONS III}

6659 OA Enhanced chemical sensing organic thin-film transistors (Invited Paper) [6659-10]

M. C. Tanese, L. Torsi, G. M. Farinola, Univ. degli Studi di Bari (Italy); L. Valli, Univ. degli Studi di Lecce (Italy); O. Hassan Omar, Univ. degli Studi di Bari (Italy); G. Giancane, Univ. degli Studi di Lecce (Italy); E. leva, F. Babudri, F. Palmisano, F. Naso, P. G. Zambonin, Univ. degli Studi di Bari (Italy) 
6659 OD Sensitivity control of optical fiber biosensors utilizing turnaround point long period gratings with self-assembled polymer coatings [6659-13]

E. Gifford, Virginia Tech (USA); Z. Wang, S. Ramachandran, OFS Labs. (USA); J. R. Heflin,

Virginia Tech (USA)

\section{POSTER SESSION}

6659 OE Advances in OLED-based oxygen sensors with structurally integrated OLED, sensor film, and thin-film Si photodetector [6659-14]

D. Ghosh, R. Shinar, Y. Cai, Z. Zhou, V. L. Dalal, J. Shinar, lowa State Univ. (USA)

Author Index 


\title{
Conference Committee
}

\author{
Symposium Chair
}

Zakya H. Kafafi, Naval Research Laboratory (USA)

Conference Chairs

Ruth Shinar, lowa State University (USA)

George G. Malliaras, Cornell University (USA)

Program Committee

Graciela B. Blanchet, DuPont Electronic Polymers (USA)

Emil J. W. List, Technische Universität Graz (Austria)

Roisin Owens, Agave BioSystems (USA)

Franky So, University of Florida (USA)

Luisa Torsi, Università degli Studi di Bari (Italy)

Session Chairs

1 Organic-Based Sensing Applications I

Luisa Torsi, Università degli Studi di Bari (Italy)

2 Organic-Based Sensing Applications II

George G. Malliaras, Cornell University (USA)

3 Organic-Based Sensing Applications III

Ruth Shinar, lowa State University (USA) 
Downloaded From: https://www.spiedigitallibrary.org/conference-proceedings-of-spie on 26 Apr 2023

Terms of Use: https://www.spiedigitallibrary.org/terms-of-use 